investigation with Marsh, about a century ago, and Stas in 1850, Dr. Roche Lynch discussed the general characteristics of poisons. With the exception of a few of animal origin, like snake venom and certain serums, tolerance toward all poisons increases with repeated small doses ; narcotics, alkaloids, metals and even castor oil. This seems to be due to growing immunity of the cells as well as to increased rate of excretion or destruction. In general, detoxication takes place mainly in the liver with increasing efficiency, the processes seeming to be developments of natural responses. Quite large amounts of the heavy metals have been found, lead up to 146 parts per million being demonstrated in normal bone where no industrial or similar causative contact had occurred. Difficulty arises with the modern synthetic medicinals; they have often only a narrow margin between the medicinal and the toxic doses and have little allowance for idiosyncrasy. Many of them are completely destroyed, or changed in the tissues into something else in a short time. The barbituric acid group are particularly dangerous, and should be brought under regulation. They are all hypnoties, but their behaviour from a toxicological point of view is very different. Some of these compounds are almost completely destroyed in the body, so that analysis only reveals a trace, and others are readily found in considerable quantity both in the excreta and in the organs. Opinion therefore as to the cause of death must depend on the type of barbiturate present and the amount isolated. Dr. Lynch then dealt in greater detail with arsenic, strychnine and carbon monoxide, illustrating his remarks with references to, and exhibits from, famous criminal cases.

\section{Conservation of the Flora of Great Britain}

In the report of the work of Flora's League, a society for the preservation of wild flowers, ferns and trees, covering the years 1932-34, the League records its work, in collaboration with other bodies, for the conservation of the British flora, and its plans for the future. In co-operation with the Cotteswold Naturalists' Field Club, the Gloucestershire station of Ranunculus ophioglossifolius, which grows in this and one other county only in England, has been secured for all time, while in Lancashire special efforts are being made to preserve the endangered flora of the sand-dunes in the vicinity of Ainsdale, the only known habitat of Epipactis dunensis. Following on the successful re-introduction of Maianthemum biflorum, the may lily, in Ken Wood, under the direction of Mr. J. S. L. Gilmour, assistant director of the Royal Botanic Gardens, Kew, the League has plans for the cultivation of rare species of wild-plants for their seeds, to sow in wild flower gardens or in haunts from which they have disappeared; though record of the site and other details of each such experiment will be reported to the Department of Botany of the British Museum (Natural History) to avoid any confusion of records of field botanists. Under the auspices of the Wild Plant Conservation Board of the Council for the Preservation of Rural England, the British Wild Plant Nurseries and Seed
Exchange Agency has been originated by Mr. C. S. Garret at Derby, for this purpose, but not to be run as a commercial profit-making concern; while the Green Cross Society and the British Empire Natur. alists' Association, affiliated organisations, have similar seed-distributing schemes. The president and founder of the League is Sir Maurice Abbot-Anderson, and it has offices at the Council for the Preservation of Rural England at 17, Great Marlborough Street, London, W.l.

\section{Meteorology in Northern Rhodesia}

The Meteorological Report for Northern Rhodesia for 1931-32 (No. 9) is the first of this series that has appeared since responsibility for the direction of meteorological work in that colony was taken over by the Director of the British East African Meteorological Service (Mr. A. Walter), for although the new service was officially inaugurated in 1929, it was not until the end of 1931 that Northern Rhodesia was included in it, control being meanwhile in the hands of the Director of Surveys. The new regime began soon after the completion of the Territorial First Order Meteorological Station at Broken Hill-a station exactly similar to the other first order stations already established in Kenya, Tanganyika and Uganda. Before the end of the year, autographic records of temperature, humidity and atmospheric pressure were in operation there, and were used for obtaining the hourly readings of these elements that appear in this report for the six months JanuaryJune 1932. The work of Broken Hill includes the distribution of forms and equipment to the subsidiary stations within the colony, the handling of all the records obtained at such stations, and the issuing of weather reports, including the results of pilot balloon ascents, to aeroplanes passing over Northern Rhodesia. The report is on the same general lines as the earlier annual reports ; it includes, in addition to statistical tables on normal lines, discussions of the separate meteorological elements, among which rainfall, as in the tropics generally, is of the greatest immediate practical importance. There is in addition an account of a waterspout that was seen near Nsalushi Island, in the swamp area of Lake Bangweolo, on February 19, 1932, and particulars of slight earth tremors reported from a number of subsidiary climatological stations.

\section{Distributing Electricity to Country Districts}

DURING the last ten years, the distribution of electricity by means of overhead lines has made rapid progress; but there are still nearly 80 per cent of the occupied rural areas of England where electric supply is not available. There is a vast amount of development work to be done in these areas. Already the capital sunk for distributing power is considerably in excess of that used for generating power. The annual expense in distribution is at the present time three times greater than that for generation. The progress already made shows that there is plenty of scope for technical improvements which would increase the factor of safety and lower the cost of 